\title{
Successful Treatment of Nocardia Farcinica Prosthetic Valvular Endocarditis without Valvular Replacement
}

\author{
Margret Jona Einarsdottir ${ }^{1, *}$, Hildur Gudmundsdottir ${ }^{2}$, Bjarni Torfason $^{1,3}$, Anna Thorisdottir ${ }^{1}$, Karl Andersen ${ }^{1,3}$, \\ Thordis Jona Hrafnkelsdottir ${ }^{1,3}$, Sigurdur Gudmundsson ${ }^{1,3}$ \\ ${ }^{1}$ Landspitali University Hospital, Reykjavik, Iceland \\ ${ }^{2}$ Hisøy Legesenter, Kolbjørnsvik, Norway \\ ${ }^{3}$ Faculty of Medicine, School of Health Sciences, University of Iceland, Reykjavik, Iceland \\ *Corresponding author: margjone@landspitali.is
}

Received April 02, 2015; Revised April 11, 2015; Accepted April 14, 2015

\begin{abstract}
We report a case of prosthetic valve nocardia endocarditis. A 43 year old farmer underwent aortic valve replacement with a bioprosthetic valve. The immediate post-operative course was uneventful but 2 weeks later he developed fever. A trans-oesophageal echocardiogram (TEE) showed a string like structure attached to the prosthetic valve. Blood cultures grew N. farcinica. He was initially treated with trimethoprim/sulfamethoxazole (TMP/SMZ), but due to eosinophilia and leucopenia his treatment was changed to imipenem and amikacin. He developed a rash, presumed to be due to imipenem, which was then substituted with linezolid. He completed a 6 week course of intravenous (i.v.) antibiotics. Desensitization with amoxicillin/clavulanic acid was successful and the patient received oral amoxicillin/clavulanic acid for 6 months. At present, 12 months from diagnosis, he is afebrile and TEE is normal. To our knowledge, this case is the fifth reported case of successful treatment of prosthetic valve nocardia endocarditis treated without surgery.
\end{abstract}

Keywords: prosthetic valve, endocarditis, Nocardia farcinica

Cite This Article: Margret Jona Einarsdottir, Hildur Gudmundsdottir, Bjarni Torfason, Anna Thorisdottir, Karl Andersen, Thordis Jona Hrafnkelsdottir, and Sigurdur Gudmundsson, "Successful Treatment of Nocardia Farcinica Prosthetic Valvular Endocarditis without Valvular Replacement.” American Journal of Medical Case Reports, vol. 3, no. 5 (2015): 121-125. doi: 10.12691/ajmcr-3-5-1.

\section{Introduction}

Nocardia is a genus of aerobic bacteria that has been isolated from soil worldwide. It can cause infection both in immunocompromised and immunocompetent hosts and has a predilection for the lungs, skin and soft tissues, as well as the central nervous system [1]. Nocardiosis is typically considered as an opportunistic infection, but approximately one-third of infected patients are immunocompetent [2]. Thirty-three Nocardia species are known to cause disease in humans with infections by members of the $\mathrm{N}$. asteroides complex (N. asteroides sensu stricto, $\mathrm{N}$. farcinica and $\mathrm{N}$. nova) being the most common worldwide [3]. Infective endocarditis caused by nocardia is very rare. We searched the PubMed and Scopus databases (the terms used for the search were nocardia, endocarditis) and only twenty cases of nocardia endocarditis have been described in the literature since 1973 [4-22]. We present the twenty-first case.

\section{Case Presentation}

The patient is a 43 year old previously healthy man. He is a sheep and cattle farmer in Iceland who also works as a fireman. He has a chronic, stable lesion on his right leg, diagnosed as lichen planus 20 years earlier. The lesion has been stable, and did not change, neither before nor during his present illness. Due to his work as a fireman he is required to have an annual physical exam where incidentally he was noted to have a crescendodecrescendo systolic murmur. He was referred for an echocardiogram that showed severe aortic stenosis due to a calcified bicuspid aortic valve with a maximum transvalvular pressure gradient as high as $90 \mathrm{mmHg}$. Although the patient remained asymptomatic at that time, he underwent subcoronary aortic valve replacement surgery on prognostic indications with a porcine Freestyle ${ }^{\circledR}$ biological prosthetic valve (Medtronic, Minneapolis, Minnesota, USA). The operation was without complications, and the immediate post-operative course was uneventful. The patient was discharged home on the $7^{\text {th }}$ postoperative day. A week later he developed fevers up to $40.4^{\circ} \mathrm{C}$ and malaise. He was seen by his general practitioner who administered oral antibiotics empirically. After 48 hours without improvement, he was admitted to Landspitali University Hospital in Reykjavik. On admission, his body temperature was $36.6^{\circ} \mathrm{C}$, blood pressure was 116/76 mm Hg, heart rate was 88 beats per minute, and his respiratory rate was 16 breaths per minute. He was not ill appearing. Cardiac and pulmonary auscultation was normal. The sternal incision was without 
signs of infection. A splinter hemorrhage was found under the fingernail of the right thumb. A red papular rash was on the right leg below the knee, unchanged from the previous admission.

Results of laboratory blood tests on admission were within normal limits except for a decreased hemoglobin level of $119 \mathrm{~g} / \mathrm{L}$ and elevated CRP $140 \mathrm{mg} / \mathrm{L}$. White blood count (WBC) was $8.0 \times 10^{6} / \mathrm{ml}$. Testing for HIV was negative. ECG showed normal sinus rhythm. A computed tomography (CT) scan of head and abdomen were normal. A CT scan of the thorax did not show any signs of infection.

The oral antibiotic treatment was discontinued on admission. A trans-esophageal echocardiogram (TEE) showed a thread-like structure in the outflow tract of the left ventricle that appeared to be attached to the prosthetic valve (Figure 1). Blood was obtained for culture. The patient received empiric treatment initially with cloxacillin and gentamicin without improvement, and the antimicrobial regimen was changed to vancomycin, gentamicin, ciprofloxacin and rifampin on the third hospital day. Five days after admission blood cultures turned positive (obtained at 3 different time points) with an organism later identified as $\mathrm{N}$. farcinica. It was sensitive to amoxicillin/clavulanic acid (MIC $1.0 \mathrm{mg} / \mathrm{l}$ ), imipenem (MIC $0.25 \mathrm{mg} / \mathrm{l}$ ), amikacin (MIC $2.0 \mathrm{mg} / \mathrm{l}$ ), trimethoprim/sulfamethoxazole (TMP/SMZ, MIC $0.094 \mathrm{mg} / \mathrm{l}$ ), ciprofloxacin (MIC $0.38 \mathrm{mg} / \mathrm{l}$ ), linezolid (MIC $1.0 \mathrm{mg} / \mathrm{l}$ ) and rifampin (MIC $0.064 \mathrm{mg} / \mathrm{l}$ ).

Upon identification of the pathogen, the antibiotic therapy was changed to i.v. TMP/SMZ. However, the patient developed eosinophilia and leukopenia after three weeks of TMP/SMZ therapy (WBC $2.0 \times 10^{6} / \mathrm{ml}$ ), which was presumed to be the cause, and treatment was again changed. Imipenem and amikacin were started but ten days later he developed an urticarial rash with throat fullness but neither wheezing nor hypotension. Imipenem was replaced with i.v. linezolid and the amikacin was continued. The rash and discomfort disappeared in less than 8 hours on H1- and H2-blockers and steroids. The patient finished a total of 6 weeks of i.v. antibiotic treatment. As recommended in the literature, the plan was to continue oral antibiotic treatment for a total of six months. The patient was rechallenged with TMP/SMZ but developed facial flushing within a few hours. The patient was discharged home on oral linezolid $600 \mathrm{mg}$ twice a day which he took for another 2 weeks.

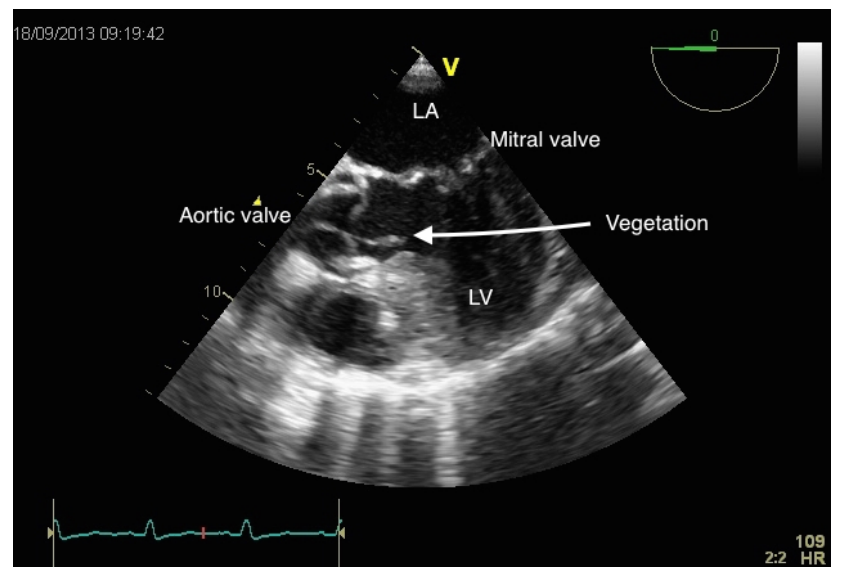

Figure 1. Trans-esophageal echocardiogram performed early in the illness. A thread-like structure is present in left ventricular outflow tract below the prosthetic aortic valve, consistent with a vegetation. LA, left atrium; LV, left ventricle

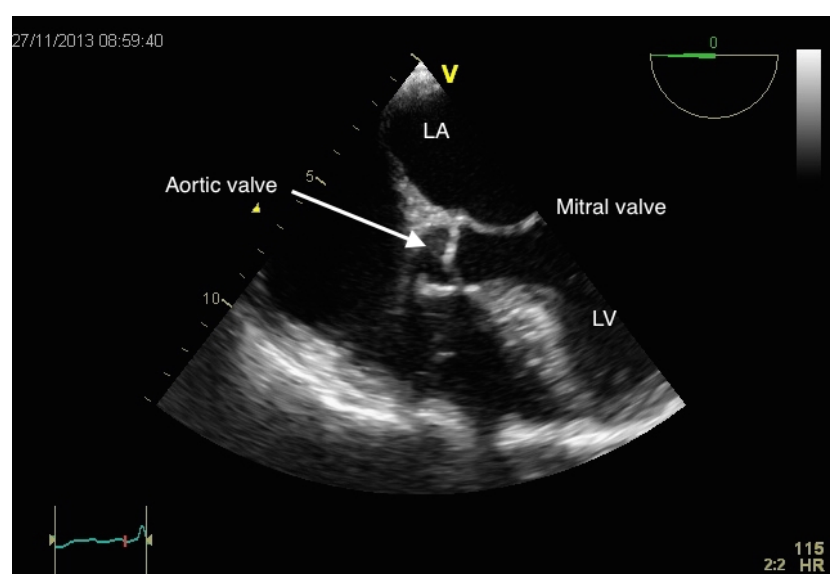

Figure 2. Trans-esophageal echocardiogram after 10 weeks of active anti-microbial treatment. The vegetation has now resolved. There are no signs of paravalvular abscess or leakage in the aortic valve. LA, left atrium; LV, left ventricle

The adverse effects of long-term linezolid therapy can be serious (thrombocytopenia, peripheral neuropathy) [23]. One of the few remaining options for prolonged oral therapy was amoxicillin/clavulanic acid. The patient underwent a radioallergosorbent test (RAST) for penicillin which was negative, but given the previous reaction to imipenem a desensitization procedure with amoxicillin/clavulanic acid was successfully performed in the intensive care unit. The patient was subsequently administered oral amoxicillin/clavulanic acid $1 \mathrm{~g}$ three times a day for 6 months without complications. Repeated TEE at the end of therapy showed complete resolution of the thread-like vegetation, and no paravalvular leak (Figure 2). Currently 7 months after completion of therapy the patient is well and back to working full time as a farmer and a fireman. His most recent WBC count was normal $\left(4.4 \times 10^{6} / \mathrm{ml}\right)$ and his ESR $14 \mathrm{~mm} /$ hour.

\section{Discussion}

We report here the case of a previously healthy immunocompetent 43 year old male with $\mathrm{N}$. farcinica endocarditis on a biological prosthetic heart valve successfully treated without valvular replacement. No evidence of dissemination to other organs was found. Of note is that the patient is a farmer, and developed symptoms of his Nocardia infection a week after discharge home to his farm. He has had a lichen planus lesion on his right leg but the lesion remained unchanged and was neither inflamed nor exudative. Thus, cultures were not obtained from the lesion. It is nevertheless intriguing to speculate that the organism originated from soil on his farm, rather than being health care-associated, but the short delay is rather puzzling. The manufacturer of the prosthetic valve (Medtronic, Minneapolis, Minnesota, USA) was contacted and no other cases of infections associated with the Freestyle ${ }^{\circledR}$ valve had been reported. A Freestyle ${ }^{\circledR}$ porcine biological valve was chosen since the patient opted against a mechanical valve because his lifestyle was poorly consistent with life-long anticoagulant therapy. Furthermore, the Freestyle ${ }^{\circledR}$ heart valve is made without a frame (stent) allowing valve movement more akin to a natural valve. In addition, the durability of the Freestyle ${ }^{\circledR}$ valve has been well demonstrated, even surpassing that of valvular homografts [24]. 
Twenty cases of nocardia endocarditis have been described in the literature since 1970 (Table 1) [4-22]. In ten of these cases a native valve was infected $[5,6,8,9,10,13,17,18,19,22]$ and in ten cases a prosthetic valve was involved [4,7,11,12,14,15,16,20,21]. Seven patients died as a result of the infection, giving a mortality rate of $35 \%[8,9,20]$. Eight of the 13 survivors were treated with valve replacement in addition to antibiotic therapy. Of the 12 patients not treated with surgery seven died. None of the patients who underwent valve replacement died. However, one patient [5] with native valve endocarditis survived without valve replacement and four patients with prosthetic valve endocarditis were successfully treated with antibiotics alone without valve replacement $[7,11,12,20]$. There have not been any other cases of nocardia prosthetic valve endocarditis treated with antibiotics alone reported in the literature since 2010 [20], and therefore ours is the fifth case.

Table 1. Cases of nocardia endocarditis reported in the literature since 1973

\begin{tabular}{|c|c|c|c|c|c|c|c|c|c|c|}
\hline Reference & $\begin{array}{c}\text { Age/ } \\
\text { Gender }\end{array}$ & $\begin{array}{c}\text { Affected } \\
\text { valve }\end{array}$ & $\begin{array}{c}\begin{array}{c}\text { Time } \\
\text { after } \\
\text { surgery } \\
\text { (months) }\end{array} \\
\end{array}$ & $\begin{array}{l}\text { Blood } \\
\text { culture }\end{array}$ & Nocardia sp. & $\begin{array}{l}\text { Echocardiographic, } \\
\text { surgical or autopsy } \\
\text { findings }\end{array}$ & $\begin{array}{l}\text { Antibiotic } \\
\text { treatment }\end{array}$ & Surgery & $\begin{array}{l}\text { Other } \\
\text { infected } \\
\text { sites }\end{array}$ & Outcome \\
\hline $\begin{array}{l}\text { Vlachakis } \\
\text { [21] } 1973\end{array}$ & $34 / F$ & PMV & $>2$ & Neg. & $\begin{array}{l}\text { Nocardia } \\
\text { asteroide }\end{array}$ & $\begin{array}{l}\text { Vegetations on the } \\
\text { mitral valve } \\
\text { (autopsy) }\end{array}$ & None & None & Skin & Died \\
\hline $\begin{array}{l}\text { Leonard } \\
\text { [18] } 1973\end{array}$ & $34 / \mathrm{F}$ & $\begin{array}{l}\text { NMV, } \\
\text { NAV }\end{array}$ & NA & NA & $\begin{array}{l}\text { Nocardia } \\
\text { asteroide }\end{array}$ & $\begin{array}{l}\text { Vegetations on the } \\
\text { mitral and aortic } \\
\text { valve (autopsy) }\end{array}$ & $\begin{array}{l}\text { NA (post } \\
\text { mortem } \\
\text { diagnosis) }\end{array}$ & None & $\begin{array}{c}\text { Cerebral } \\
\text { abscesses }\end{array}$ & Died \\
\hline $\begin{array}{c}\text { Falk [16] } \\
1979 \\
\end{array}$ & $64 / F$ & PAV & $>2$ & Neg. & $\begin{array}{l}\text { Nocardia } \\
\text { asteroide }\end{array}$ & $\begin{array}{c}\text { Vegetations } \\
\text { (autopsy) }\end{array}$ & $\begin{array}{l}\text { Gentamicin } \\
+ \text { ampicillin }\end{array}$ & None & Left kidney & Died \\
\hline $\begin{array}{l}\text { Allevato } \\
\text { [4] } 1985\end{array}$ & $53 / \mathrm{M}$ & $\begin{array}{l}\mathrm{PAV}+ \\
\text { aortitis }\end{array}$ & $>2$ & Pos. & $\begin{array}{l}\text { Nocardia } \\
\text { asteroide }\end{array}$ & $\begin{array}{l}\text { Vegetation and } \\
\text { perforation of the } \\
\text { aorta (autopsy) }\end{array}$ & $\begin{array}{l}\text { Streptomycin } \\
\text { + Tetracycine } \\
\text { +Sulfonamide } \\
\text { +Vancomycin }\end{array}$ & None & $\begin{array}{l}\text { Spleen, both } \\
\text { kidney }\end{array}$ & Died \\
\hline $\begin{array}{c}\text { Ertl [15] } \\
1987\end{array}$ & $61 / \mathrm{M}$ & PAV & $<2$ & Pos. & $\begin{array}{l}\text { Nocardia } \\
\text { asteroide }\end{array}$ & $\begin{array}{l}\text { Aneurysm of the } \\
\text { non-coronary sinus } \\
\text { of Valsalva } \\
\text { (surgery) }\end{array}$ & $\begin{array}{l}\text { AMK +IMP + } \\
\text { TMP/SMX + } \\
\text { co-amoxiclav }\end{array}$ & AVR & NR & Survived \\
\hline $\begin{array}{c}\text { Eigel [14] } \\
1988\end{array}$ & $61 / \mathrm{M}$ & PAV & $<2$ & Pos. & $\begin{array}{l}\text { Nocardia } \\
\text { asteroide }\end{array}$ & Aorta root aneurysm & $\begin{array}{l}\text { IMP/cilastatin } \\
\text { + AMK, } \\
\text { cefotiam }\end{array}$ & AVR & NR & Survived \\
\hline $\begin{array}{c}\text { Eigel [14] } \\
1988\end{array}$ & 65/M & PAV & $<2$ & Pos. & $\begin{array}{l}\text { Nocardia } \\
\text { asteroide }\end{array}$ & $\begin{array}{l}\text { Aorta root } \\
\text { Aneurysm }\end{array}$ & None & None & $\begin{array}{c}\text { Sternal } \\
\text { osteomyelitis }\end{array}$ & Died \\
\hline $\begin{array}{c}\text { Ayral [7] } \\
1989\end{array}$ & $68 / \mathrm{M}$ & PAV & $>2$ & Neg. & $\begin{array}{l}\text { Nocardia } \\
\text { asteroide }\end{array}$ & $\begin{array}{c}\text { Hepatic artery } \\
\text { aneurysm }\end{array}$ & $\begin{array}{c}\text { AMK + } \\
\text { TMP/SMX }\end{array}$ & None & $\begin{array}{l}\text { Hepatic } \\
\text { artery }\end{array}$ & Survived \\
\hline $\begin{array}{c}\text { Niehues } \\
\text { [19] } 1996\end{array}$ & $62 / \mathrm{M}$ & NAV & NA & Neg. & $\begin{array}{l}\text { Nocardia } \\
\text { asteroide }\end{array}$ & Vegetation (TEE) & $\begin{array}{l}\text { IMP/cilastatin } \\
+ \text { doxycycline }\end{array}$ & None & $\begin{array}{l}\text { Skin, brain, } \\
\text { lung }\end{array}$ & Died \\
\hline $\begin{array}{l}\text { Dhawan } \\
\text { [13] } 1998\end{array}$ & $46 / \mathrm{F}$ & NMV & NA & Neg. & Nocardia spp. & $\begin{array}{c}\text { Vegetation } \\
\text { (transthoracic } \\
\text { echocardiography) }\end{array}$ & $\begin{array}{l}\text { TMP/SMX+ } \\
\text { IMP/cilastatin }\end{array}$ & MVR & Skin & Survived \\
\hline $\begin{array}{l}\text { Watson } \\
\text { [22] } 2001\end{array}$ & 39/M & NAV & NA & Pos. & $\begin{array}{l}\text { Nocardia } \\
\text { asteroide }\end{array}$ & $\begin{array}{l}\text { Vegetation +aortic } \\
\text { ring abscess } \\
\text { (transthoracic } \\
\text { echocardiography) }\end{array}$ & $\begin{array}{c}\text { Meropenem } \\
+ \text { AMK + } \\
\text { cefpodoxime+ } \\
\text { TMP/SMX + } \\
\text { ceftriaxone }\end{array}$ & AVR & $\begin{array}{l}\text { Embolic skin } \\
\text { lesion }\end{array}$ & Survived \\
\hline $\begin{array}{c}\text { Daikos } \\
{[12] 2003}\end{array}$ & $61 / F$ & PAV & $<2$ & Pos. & $\begin{array}{l}\text { Nocardia } \\
\text { asteroide }\end{array}$ & NA & $\begin{array}{l}\text { IMP + AMK+ } \\
\text { TMP/SMX }\end{array}$ & None & $\begin{array}{c}\text { Embolic skin } \\
\text { lesion }\end{array}$ & Survived \\
\hline $\begin{array}{c}\text { Lazo } \\
\text { Torres [17] } \\
2004\end{array}$ & $43 / F$ & NMV & NA & Neg. & Nocardia spp. & $\begin{array}{c}\text { Vegetation +mitral } \\
\text { perforaton } \\
\text { (echocardiography) }\end{array}$ & IMP+AMK & MVR & NR & Survived \\
\hline $\begin{array}{l}\text { Antonovich } \\
\text { [5] } 2004\end{array}$ & $83 / \mathrm{F}$ & NMV & NA & Pos. & $\begin{array}{l}\text { Nocardia } \\
\text { asteroide }\end{array}$ & $\begin{array}{c}\text { Vegetation } \\
\text { (echocardiography) }\end{array}$ & TMP/SMX & None & Skin & Survived \\
\hline $\begin{array}{c}\text { Antony [6] } \\
2006\end{array}$ & $74 / \mathrm{F}$ & NMV & NA & Pos. & $\begin{array}{l}\text { Nocardia } \\
\text { asteroide }\end{array}$ & $\begin{array}{c}\text { Vegetation } \\
\text { (echocardiography) }\end{array}$ & $\begin{array}{c}\text { IMP+ } \\
\text { TMP/SMX }\end{array}$ & MVR & NR & Survived \\
\hline $\begin{array}{l}\text { Chedid } \\
\text { [11] } 2007\end{array}$ & $40 / \mathrm{M}$ & PAV & $>2$ & Pos. & Nocardia spp. & $\begin{array}{c}\text { Vegetation } \\
\text { (transthoracic } \\
\text { echocardiography) }\end{array}$ & $\begin{array}{c}\text { Sulfadiazine } \\
\text { + AMK + } \\
\text { TMP/SMX }\end{array}$ & None & Phlebitis & Survived \\
\hline $\begin{array}{l}\text { Chain [10] } \\
2007\end{array}$ & 51/M & $\begin{array}{l}\text { NAV, } \\
\text { NTV }\end{array}$ & NA & Pos. & Nocardia spp. & Vegetation (TEE) & $\begin{array}{l}\text { AMK+ IMP+ } \\
\text { TMP/SMX }\end{array}$ & AVR & NR & Survived \\
\hline $\begin{array}{l}\text { Timoteo } \\
{[20] 2010}\end{array}$ & $68 / F$ & $\begin{array}{l}\text { PAV, } \\
\text { PMV }\end{array}$ & $>2$ & Pos. & Nocardia spp. & Vegetation (TEE) & TMP/SMX & None & $\begin{array}{c}\text { Eembolic } \\
\text { skin lesion }\end{array}$ & Survived \\
\hline $\begin{array}{l}\text { Cargill [8] } \\
\quad 2010\end{array}$ & $85 / F$ & NMV & NA & Neg. & $\begin{array}{c}\text { Nocardia } \\
\text { cyriacigeorgic }\end{array}$ & $\begin{array}{c}\text { Vegetation } \\
\text { (transthoracic } \\
\text { echocardiography) }\end{array}$ & $\mathrm{AMK}+\mathrm{IMP}$ & None & Skin & Died \\
\hline $\begin{array}{l}\text { Castelli [9] } \\
2011\end{array}$ & $36 / \mathrm{M}$ & NMV & NA & Neg. & Nocardia sp. & Vegetation (TEE) & TMP/SMX & MVR & NR & Survived \\
\hline This report & $43 / \mathrm{M}$ & PAV & $<2$ & Pos. & $\begin{array}{l}\text { Nocardia } \\
\text { farcinica }\end{array}$ & Vegetation (TEE) & $\begin{array}{l}\text { TMP/SMX, } \\
\text { AMK+ IMP, } \\
\text { co-amoxiclav }\end{array}$ & None & $\begin{array}{l}\text { Embolic skin } \\
\text { lesion }\end{array}$ & Survived \\
\hline
\end{tabular}

AMK, Amikacin; AVR, aortic valve replacement; co-amoxiclav, amoxicillin/clavulanic acid; F, female; IMP, imipenem; M, male; MVR, mitral valve replacement; NA, not applicable; NAV, native aortic valve; Neg., negative; NMV, native mitral valve; NR, not reported; NTV, native tricuspid valve; PAV, prosthetic aortic valve; PMV, prosthetic mitral valve; Pos., positive; TEE, Transoesophageal echocardiography; TMP/SMX, trimetoprim sulfametoxazole. 
The American College of Cardiology/American Heart Association (ACC/AHA) guidelines on the management of valvular heart disease include recommendations for surgery in patients with prosthetic and native valve endocarditis [25]. Surgery is indicated for patients with prosthetic valve endocarditis and valve dysfunction causing heart failure, evidence of paravalvular abscess, fistula formation, or heart block, relapse after optimal medical therapy, and infection with resistant organisms or fungi. Our case does not fulfill these citeria. However, Nocardia is not specificially mentioned in these guidelines, but by inference must be regarded as a difficult to-treat organism, severe infections generally treated for 6-12 months $[11,12,13,20,26]$. It is, of course, impossible to draw significant general conclusions from only 20 previously reported cases, but the early case reports on Nocardia endocarditis $[12,13,14,22]$ emphasize the value of valvular surgery. Thus here we report the fifth case of successful treatment without valve replacement.

All but one previous case of nocardia endocarditis have either been due to $\mathrm{N}$. asteroides complex or not identified as subspecies. One previous case has been reported being due to N. farcinica [15], although nomenclature changes may confuse that issue. N. asteroides was formerly considered the most common species associated with human disease, but has been redefined as a complex that includes among others N. farcinica [27]. Furthermore, N. farcinica appears to be more virulent than the other members of the $\mathrm{N}$. asteroides complex, since infection with this species is more likely to result in disseminated disease and tends to be more resistant to antimicrobials, especially third-generation cephalosporins and tobramycin [28]. No prospective randomized trials have determined the most effective therapy for nocardiosis, and it is not likely that such a trial will be performed. Thus, the choice of antimicrobials is based upon cumulative retrospective experience [26], investigations in animal models, and in vitro antimicrobial activity profiles [29]. The optimal therapeutic approach is still undetermined and depends on speciation, but lower mortality and relapse rates have been reported with a combination of targeted antimicrobial treatment including TMP-SMZ for more than 6 months [26]. In addition, synergism of imipenem and amikacin in combination with other agents, including TMP/SMZ, has been demonstrated, whereas the interaction of imipenem and amikacin is mainly additive [30]. Thus, there is consensus that the mainstay of therapy against severe nocardia infections be based on TMP/SMZ with the addition of imipenem. In patients with central nervous system disease who have multiorgan involvement, amikacin may be added to that regimen [29]. Although limited clinical experience suggests efficacy with linezolid, even as monotherapy [31] the use of linezolid for more than two weeks is associated with risk of hematologic toxicity, particularly thrombocytopenia, as well as neurotoxicity (e.g. peripheral neuropathy, serotonin syndrome) [23].

Thus, we elected initially to administer imipenem and amikacin after our patient developed hypersensitivity against TMP/SMZ, and subsequently a combination of linezolid and amikacin after the patient developed urticaria and throat symptoms most likely associated with imipenem. We furthermore elected and were more comfortable with desensitizing the patient with amoxicillin/clavulanic acid and employing that agent for long term treatment, rather than to desensitize him with TMP/SMZ. The treatment was successful and seven months after completion of antibiotic therapy we consider our patient to be cured. We believe this patient to be the fifth reported case of successfully treated prosthetic valve nocardia endocarditis managed with antibiotics alone without removal of the prosthesis.

\section{References}

[1] McNeil M.M., Brown J.M., "The medically important aerobic actinomycetes: epidemiology and microbiology," Clinical microbiology reviews, 7(3), 357-417, Jul.1994.

[2] Beaman B.L., Beaman L., "Nocardia species: host-parasite relationships," Clinical microbiology reviews, 7(2),213-264, Apr.1994.

[3] Patrick R.M., Ellen Jo B., Manual of clinical microbiology. 9th ed, ASM Press, Washington, DC 2007.

[4] Allevato P.A., Eisses J.F., Mezger E., Fisher E.J., Romig D.A., Morales A.R.,"Nocardia asteroides aortitis with perforation of the aorta," Human pathology, 16(7),743-746, Jul.1985.

[5] Antonovich D.D., Berke A., Grant-Kels J.M., Fung M.,"Infectious eccrine hidradenitis caused by Nocardia," Journal of the American Academy of Dermatology, 50(2), 315-318, Feb.2004.

[6] Antony S.J., Stivers M., Riveria J.O., "Endocarditis/endovascular infection associated with Nocardia," Infections in medicine, 23(6), Jun.2006.

[7] Ayral X., Piette A.M., Roullet-Audy J.C., Gepner P., Baillet A., Baglin A.C., et al.,"[Endocarditis caused by Nocardia asteroides on an aortic bioprosthesis complicated by a mycotic hepatic aneurysm]," Annales de médecine interne, 140(7),652-654, 1989.

[8] Cargill J.S., Boyd G.J., Weightman N.C., "Nocardia cyriacigeorgica: a case of endocarditis with disseminated softtissue infection," Journal of medical microbiology, 59(Pt 2),224230, Feb.2010.

[9] Castelli J.B., Siciliano R.F., Abdala E., Aiello V.D., "Infectious endocarditis caused by Nocardia sp.: histological morphology as a guide for the specific diagnosis," The Brazilian journal of infectious diseases: an official publication of the Brazilian Society of Infectious Diseases, 15(4),384-386, Jul-Aug.2011.

[10] Chain S., Luciardi H., Feldman G., Berman S., Estrella C.,"[Nocardia endocarditis in aortic and tricuspid native valves]," Medicina (B Aires), 67(3),279-281, 2007.

[11] Chedid M.B., Chedid M.F., Porto N.S., Severo C.B., Severo L.C.,"Nocardial infections: report of 22 cases," Revista do Instituto de Medicina Tropical de Sao Paulo, 49(4),239-246, JulAug.2007.

[12] Daikos G.L., Syriopoulou V., Horianopoulou M., Kanellopoulou M., Martsoukou M., Papafrangas E.,"Successful antimicrobial chemotherapy for nocardia asteroides prosthetic valve endocarditis," The American journal of medicine, 115(4), 330-332, Sep.2003.

[13] Dhawan V.K., Gadgil U.G., Paliwal Y.K., Chaurushiya P.S., Trivedi R.R.,"Native valve endocarditis due to a Nocardia-like organism," Clinical infectious diseases : an official publication of the Infectious Diseases Society of America, 27(4),902-904, Oct.1998.

[14] Eigel P., Elert O., Hopp H., Silber R., Romen W., Schmidt-Rotte H.,"Nocardial endocarditis after aortic valve replacement. Reports of two cases," Scandinavian journal of thoracic and cardiovascular surgery, 22(3),289-290, 1988.

[15] Ertl G., Schaal K.P., Kochsiek K.,"Nocardial endocarditis of an aortic valve prosthesis," British heart journal, 57(4),384-386, Apr.1987.

[16] Falk R.H., Dimock F.R., Sharkey J.,"Prosthetic valve endocarditis resulting from Nocardia asteroides," British heart journal, 41(1), 125-127, Jan.1979.

[17] Lazo Torres A.M., Galvez Contreras C., Collado Romacho A., Gamir Ruiz F.J., Yelamos Rodriguez F., Lopez Martinez G.,"Nocardia endocarditis in a native mitral valve," Revista espanola de cardiologia (English ed.), 57(8),787-788, Aug.2004.

[18] Leonard A., Raij L., Comty C.M., Wathen R., Rattazzi T., Shapiro F.L.,"Experience with endocarditis in a large kidney disease 
program," Transactions - American Society for Artificial Internal Organs, 19,298-301, Apr.1973.

[19] Niehues R., Schluter S., Kramer A., Klein R.M., Strauer B.E., Schaal K.P., et al., "[Systemic Nocardia asteroides infection with endocardial involvement in a patient undergoing immunosuppressive therapy]," Deutsche medizinische Wochenschrift (1946), 121(45), 1390-1395, Nov 8.1996.

[20] Timoteo A.T., Branco L.M., Pinto M., Bico P., Ferreira R.C.,"Nocardial endocarditis after mitral valve replacement: case report and review of the literature," Revista portuguesa de cardiologia: orgao oficial da Sociedade Portuguesa de Cardiologia, 29(2),291-297, Feb.2010.

[21] Vlachakis N.D., Gazes P.C., Hairston P.,"Nocardial endocarditis following mitral valve replacement," Chest, 63(2),276-278, Feb.1973.

[22] Watson A., French P., Wilson M.,"Nocardia asteroides native valve endocarditis," Clinical infectious diseases : an official publication of the Infectious Diseases Society of America, 32(4),660-661, Feb 15.2001.

[23] Bishop E., Melvani S., Howden B.P., Charles P.G., Grayson M.L.,"Good clinical outcomes but high rates of adverse reactions during linezolid therapy for serious infections: a proposed protocol for monitoring therapy in complex patients," Antimicrobial agents and chemotherapy, 50(4),1599-1602, Apr.2006.

[24] El-Hamamsy I., Clark L., Stevens L.M., Sarang Z., Melina G., Takkenberg J.J., et al.,"Late outcomes following freestyle versus homograft aortic root replacement: results from a prospective randomized trial," Journal of the American College of Cardiology, 55(4),368-376, Jan 26.2010.
[25] Nishimura R.A., Otto C.M., Bonow R.O., Carabello B.A., Erwin J.P., 3rd, Guyton R.A., et al.,"2014 AHA/ACC guideline for the management of patients with valvular heart disease: a report of the American College of Cardiology/American Heart Association Task Force on Practice Guidelines," J Thorac Cardiovasc Surg, 148(1),e1-e132, Jul.2014.

[26] Anagnostou T., Arvanitis M., Kourkoumpetis T.K., Desalermos A., Carneiro H.A., Mylonakis E.,"Nocardiosis of the central nervous system: experience from a general hospital and review of 84 cases from the literature," Medicine (Baltimore), 93(1),19-32, Jan.2014.

[27] Mandell G.L., Bennett J.E., Dolin R., Mandell, Douglas, and Bennett's principles and practice of infectious diseases, Churchill Livingstone/Elsevier, Philadelphia: 2010, 3199 p.

[28] Cercenado E., Marin M., Sanchez-Martinez M., Cuevas O., Martinez-Alarcon J., Bouza E.,"In vitro activities of tigecycline and eight other antimicrobials against different Nocardia species identified by molecular methods," Antimicrobial agents and chemotherapy, 51(3),1102-1104, Mar.2007.

[29] Spelman D. Treatment of Nocardiosis 2014 [cited 201421 Oct ]. Available from: http://www.uptodate.com/contents/treatment-ofnocardiosis

[30] Gombert M.E., Aulicino T.M.,"Synergism of imipenem and amikacin in combination with other antibiotics against Nocardia asteroides," Antimicrobial agents and chemotherapy, 24(5),810811, Nov.1983.

[31] Moylett E.H., Pacheco S.E., Brown-Elliott B.A., Perry T.R., Buescher E.S., Birmingham M.C., et al.,"Clinical experience with linezolid for the treatment of nocardia infection," Clinical infectious diseases : an official publication of the Infectious Diseases Society of America, 36(3),313-318, Feb 1.2003. 